\title{
ENVIRONMENTAL DEGRADATION IN SEMIARID BRASILIAN: AN APLICATION OF SUSTAINABILITY INDICATORS IN MUNICIPALITIES WITH CONSERVATION UNITS
}

\author{
T. S. SILVA*, E. M. X. FREIRE and G. A. CANDIDO \\ Universidade Federal do Rio Grande do Norte \\ thaisesousa@hotmail.com*
}

Article submitted in September/2013 and approved in January/2016

DOI: $10.15628 /$ holos. 2016.1680

\begin{abstract}
The Brazilian semiarid has a unique Domain, the Caatinga, which is subject to various anthropogenic pressures causing numerous problems, a mong them environmental degradation, which stands out from other phenomena due to a direct influence on the sustainability of the Caatinga. One of the most used tools to measure environmental sustainability is the system of sustainability indicators Pressure-State-ImpactResponse, applied in this study to measure the sustainability of an environmental degradation and to obtain a diagnosis of the Caatinga degradation in three
\end{abstract}

municipalities of the State of Rio Grande do Norte that adopt different environmental management practices. The municipalities are Serra Negra do Norte, Jucurutu and Tenente Laurentino Cruz. This analysis is a tool that could provide support for a planning aiming to improve quality of life and environmental sustainability, as these three municipalities have similar characteristics and distinct forms of environmental management. They can be compared and evaluated in terms of contribution to the conservation of Caatinga.

KEYWORDS: Environmental Management, Pressure State Impact Response, Conservation of Caatinga.

\section{DEGRADAÇÃO AMBIENTAL NO SEMIÁRIDO BRASILEIRO: UMA APLICAÇÃO DE INDICADORES DE SUSTENTABILIDADE EM MUNICÍPIOS COM UNIDADES DE CONSERVAÇÃO}

\section{RESUMO}

O semiárido brasileiro possui um Domínio exclusivo, a Caatinga, que está submetida a diversas pressões antrópicas causadoras de inúmeros problemas, dentre os quais a degradação ambiental, a qual se sobressai de outros fenômenos por ter influência direta na sustentabilidade da Caatinga. Uma das ferramentas mais utilizadas para mensurar a sustentabilidade ambiental é o sistema de indicadores de sustentabilidade PressãoEstado-Impacto-Resposta, aplicado neste estudo para mensurar a sustentabilidade no âmbito da degradação ambiental, para obter um diagnóstico dessa degradação da caatinga em três municípios do Estado do Rio Grande do Norte, que adotam práticas diferenciadas de gestão ambiental, são eles: Serra Negra do Norte, Jucurutu e Tenente Laurentino Cruz. Esta análise constitui um instrumento que pode fornecer subsídios para um planejamento que tenha por meta a qualidade de vida e a sustentabilidade ambiental, pois esses três municípios possuem características semel hantes e formas de gestão a mbiental distintas, podendo ser comparados e avaliados em termos de contribuição para a conservação da Caatinga.

PALAVRAS-CHAVE: Gestão Ambiental, Pressão Estado Impacto Resposta, Conservação da Caatinga. 


\section{INTRODUCTION}

The environmental degradation to which the planet is subject has been greatly intensified throughout the history of humanity. Because of it, man's attention turned to new attitudes toward more sustainable practices.

The occupation of northeastern Brazil towards its countryside was made by extractive activities and agricultural production focused on export (ALVES et al., 2008). These activities have always been important to the economy. In this context, however, the environment was always in the background.

Caatingas are one of the most different vegetation types studied by researchers from different backgrounds and origins. They studied its floristic, structural and physiognomy characteristics and its dynamism (FREIRE et al., 2011). Other authors argue that all characteristics of the current Caatinga are the result of anthropogenic degradation, and the climax of it is the dry forest (ALVES et al., 2008,6]. The consequences of environmental impacts such as fire, extensive cattle ranching, agricultural systems and plant extraction were at the origin of these transformations (ALVES, 2009).

Considering its weaknesses and strengths, the Caatinga is more valued in recent decades. Recent research results (BRASIL, 2012) contribute to the creation of new Conservation Units. However, much must to be done so that the Caatinga is properly conserved and restored.

Also according to Brasil (2012), the situation of the Caatinga is evaluated as critical regarding the susceptibility to desertification due to environmental degradation, to which it is subjected. In addition, studies show the extent of the increasingly environmental degradation in the Caatinga and the harm caused to local communities (PRUDÊNCIO and CÂNDIDO, 2009; ALVES, 2009; FERNANDES et al., 2005).

Given this scenario, means of evaluating sustainable development are being structured and tested with emphasis on the use of environmental indicators measuring the damage caused to the environment, so that relations between the state of environmental damage and possible actions to be taken within a plan aimed at reducing negative impacts are identified. In the specific case of the Caatinga, the indicators may diagnose the state of degradation at different levels and under various forms of management (CANDIDO et al., 2002).

The Seridó of Rio Grande do Norte comprises an extensive area of the Caatinga, where numerous activities are developed, including disorderly use and occupation, thus giving rise to environmental degradation situations (VIDAL, 2003). In Rio Grande do Norte and in that region, the only federal Conservation Unit is the Ecological Station of Seridó (ES Seridó), a Conservation Unit (CU) with full protection. Another CU in the Seridó Caatinga, but with a sustainable use, is the Private Natural Heritage Reserve (PNHR) Stoessel de Brito. On the other hand, equally important areas in this region, such as the Serra de Santana and specifically the municipality of Tenente Laurentino Cruz, have an extensive natural area not protected. Although in those areas different forms of environmental management are used, they suffer from environmental degradation processes due to the same causes, which allows us to compare them using Sustainability Indicators.

Accordingly, the objective of this study is to measure the sustainability of municipalities with Conservation Units in Caatinga areas in the Rio Grande do Norte state from the analysis of 
environmental degradation levels using a set of specific indicators after an adaptation of the methodology recommended by the system of indicators Pressure-State-Impact-Response (PSIR).

The System of sustainability indicators Pressure-State-Impact-Response (PSIR) developed by the Organization for Economic Co-operation and Development (OECD, 2004) is applied to small areas where there are anthropogenic interferences to measure and/or analyze their environmental quality and sensitize the authorities and the society toward making decisions on the maintenance of environmental sustainability and human actions that interfere in the environment (ALVES, 2009) including two or more scenarios (NOBRE et al., 2010). In addition, it is applied to the measurement of environmental degradation (SEKOVSKI et al., 2012).

In this introductory content, the article explores the theoretical aspects of sustainability, the PSIR method and environmental degradation in the Caatinga. After that, the methodological procedures used, the results and the final considerations are presented.

\section{LITERATURE REVIEW}

\subsection{Environmental degradation in the Caatinga}

Environmental degradation is understood as changes in natural conditions that compromise the use of natural resources (soil, water, flora, fauna etc.) and reduce the quality of life (DIAS, 1998)

According to Silva and Ribeiro (2004), environmental degradation is also characterized by deforestation, removal of forest and burning of vegetation aiming to increase clean areas for economic activities such as agriculture and livestock.

The degradation of natural resources in the Caatinga has increased intensely, reaching critical levels, which impact on environmental degradation (BERTONI and LOMBARDI NETO, 1990) and thus cause economic, environmental and social losses, whether in urban or rural areas (ALVES et al., 2008).

For long, the idea that the Caatinga was the result of the degradation of more exuberant vegetation, such as the Atlantic Forest or the Amazon rainforest, prevailed. That thought produced the false idea that this domain was homogeneous, low in species and endemism, being little changed or threatened since the beginning of the colonization of Brazil (ALVES et al., 2008). Currently, the environmental degradation of the Caatinga, which occupies $12 \%$ of the country, is strongly linked to the factors use and occupation of the soil, since the forms of occupation and management causes different types and degrees of impact that affect differently the environment.

Overgrazing, high population density recorded in several locations, constant deforestation and environmental management without planning cause serious erosion problems and the reduction of potential soil fertility in most part of the Caatinga (MONTEIRO, 1995). This destabilizes the dynamics of the environment and affects the quality of life of populations, generating a negative environmental impact. This impact is caused by the destruction, removal or exclusion of native flora and fauna, by the loss or removal of the fertile soil layer, by the change in quality and flow regimes of water systems and by the generation of pollution and contamination of natural resources (BROLLO, 2001; BROLLO et al., 2002). In most cases, economic activities are 
accompanied by an indiscriminate deforestation of the Caatinga, which, together with the natural fragility of the ecosystem, results in serious consequences including to the resident population.

The human being, upon transforming the environment in order to make it suitable for its needs (TOYNBEE, 1974), generated a multitude of environmental problems. These problems impacted negatively on the quality of life of communities. Thus, the environmental planning can be seen as a way to anticipate activities that may cause damages to the environment. However, in order to enable planning appropriately and sustainably, the measurement of environmental sustainability is needed. This study proposes such an analysis from the environmental degradation Problem already observed in Caatinga areas that are object of this study.

\subsection{Sustainable Development and Sustainability Indicators}

The concern about deforestation and the accelerated degradation process in the Caatinga has led researchers, government agencies, NGOs, the private sector and many other social actors to engage in the pursuit of a sustainable economic development for the Northeast region.

To minimize this destructive process, it is necessary to contain the spread of desertification with social and technological measures to be adopted by all social segments within this area, involving not only government officials, but also, and above all, the civil and organized society (MENEGUZZO, 2006). The solution may be in a sustainable development based on the durability of economic growth, nature conservation and social equity.

In an attempt to measure the level of sustainability of certain areas, a number of tools and systems was developed to assess the degree of environmental development, i.e., the systems of indicators. They are comprised of important parameters to focus on the reality within a multidisciplinary context with the purpose of providing information necessaryfor decision-making.

In this evaluation, the indicators are important especially because they help to report the conditions of complex and interdependent systems and promote the evaluation of performance of several types of management and policies in a locality in relation to sustainability. Many tools can be used to measure sustainable development. The choice depends on the environment and on the context to which they will be applied. Degradation, as an environmental problem visible in the Caatinga, refers us to the application of a system of indicators to where environmental problems are prevalent. One of these indicators is the Sustainability Indicator System Pressure-State-ImpactResponse (PSIR).

\subsection{The Pressure-State-Impact-Response model}

The PSIR (Pressure-State-Impact-Response) is characterized as a communication program that aims to raise awareness on environmental issues, providing action options through which it becomes possible to analyze corrective measures (VIEIRA, 2007), to adopt new directions in dealing with environmental problems and to identify skills and responsibility levels of committed social actors.

In this point of view, the environmental problem is introduced. The constant search for a new paradigm for a correct management is seen as one of the greatest challenges of the beginning of this new millennium. This is because the solutions previously found and put into practice are not yet considered as unique and universally accepted. In this sense, it is necessary to stress that the 
variables that compose the PSIR indicator are defined and established based on the consultation with several authors relevant to the environmental degradation issue. Since it is an indicator that assesses the environmental quality of a particular location or situation (OECD, 2007), it is considered a variable dependent on the reality researched.

In terms of the most widespread applications and practices for the measurement of environmental problems, the PSIR prevails as a methodology of evaluation of environmental impacts. It provides a general mechanism for analyzing environmental problems that does not reject the idea that the environment exists as a multi-interaction system (CARVALHO and BARCELLOS, 2009).

This methodology aims to present environmental information in order to answer four basic questions: Why is this happening? (Pressure); what is happening to the environment? (State); what are the consequences of environmental degradation? (Impact); and what is being done about it? (Response). Based on this model, depending on the purpose for which the PSIR is used, this can easily be adapted according to a need for a greater accuracy or with particular characteristics. It should be applied to areas where environmental problems stand out from other areas, such as municipalities and their areas in this study in relation to the environmental degradation in the Caatinga.

The PSIR has advantages because it is easily adjustable to different realities and thus may be an important tool for decision-making by public management (CHUNG and LEE, 2009), especially because it shows the link between the various elements that make up the environmental system and because it differentiates itself by offering managers a more accurate assessment of the environmental situation and the consequences of land occupation policies (ARIZA and NETO, 2010).

Admitting environmental degradation to be currently a major factor because of its negative effects on the planet, the measurement of the magnitude of this process in Caatinga using the PSIR Sustainability Indicator model is applied in this work based on a set of variables. This model assumes that there are a number of mitigating activities (responses) and treatments that can be performed to reduce environmental impacts using practices determined by studying these factors (HUANG et al., 2011).

Therefore, this methodology is applied to Caatinga areas that are under different environmental managements, but with the same environmental problems, especially Degradation, in order to measure the sustainability of these regions.

\section{METHODOLOGY}

\subsection{Characterization of research}

The research is descriptive and exploratory, descriptive because it describes the context of Conservation Units regarding the existing environmental degradation in the Caatinga, and exploratory because it uses Sustainability Indicators not yet applied to Conservation Units and natural areas.

The Perspective of choosing PSIR is related to the fact that it should be primarily used when there is a serious and major environmental problem in the studied geographical scope, which is 
embodied by the environmental degradation problem resulting from activities in Seridó Caatinga areas.

\subsection{Selection of Research Variables}

The PSIR system was structured so that Pressure, State, Impact and Response were classified as dimensions composed of variables using the Sustainable Development Indicators - SDI Brazil (IBGE IDS, 2010, 2012) as a matrix for the design and analysis of this system. The dimensions form a Sustainability Indicator System with information on the monitoring of the sustainability of the country's development pattern and important issues for the current debates on Brazil's situation. Currently, the Brazilian SDI is divided into four areas: Environmental, Social, Economic and Institutional (IBGE IDS, 2012).

Table 1. Sustainability indicators to assess the environmental degradation in the Caatinga areas under study.

\begin{tabular}{|c|c|c|c|}
\hline \multirow{2}{*}{ DIMENSION } & \multirow{2}{*}{ VARIABLE } & \multicolumn{2}{|c|}{ Sustainability Assessment parameter } \\
\hline & & Favorable & Unfavorable \\
\hline \multirow{7}{*}{ 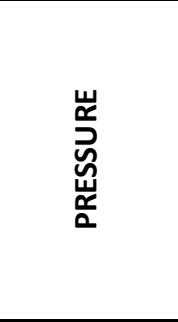 } & Use of fertilizers and pesticides & Absence & Presence \\
\hline & Surrounding lands with an agrosylvopastoral use & Absence & Presence \\
\hline & Factories and small industries & Absence & Presence \\
\hline & Fires & Absence & Presence \\
\hline & Invasive species & Absence & Presence \\
\hline & Hunting of endangered animals & Absence & Presence \\
\hline & Plant extraction & Absence & Presence \\
\hline \multirow{10}{*}{ 㟶 } & Vegetation cover & Presence & Absence \\
\hline & Native fauna diversity & Presence & Absence \\
\hline & Native flora diversity & Presence & Absence \\
\hline & Degraded areas & Absence & Presence \\
\hline & Protected areas (Conservation Units) & Presence & Absence \\
\hline & Extinct and/or endangered species & Absence & Presence \\
\hline & Housing adequacy & Presence & Absence \\
\hline & Mapping of degraded area & Presence & Absence \\
\hline & Pollution of water resources & Absence & Presence \\
\hline & Desertification & Absence & Presence \\
\hline \multirow{6}{*}{$\frac{\mathfrak{\swarrow}}{\grave{a}}$} & Abandoned domestic animals & Absence & Presence \\
\hline & Contamination by solid waste (litter) & Absence & Presence \\
\hline & Reduction in the productivity of properties & Absence & Presence \\
\hline & Sociocultural projects & Presence & Absence \\
\hline & Control of exotic fauna and flora & Presence & Absence \\
\hline & Spending on Research and Development & Presence & Absence \\
\hline \multirow{6}{*}{ 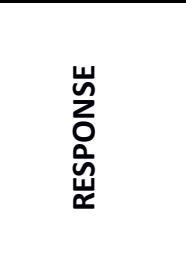 } & Associations or environmental cooperatives & Presence & Absence \\
\hline & Environmental management public policies & Presence & Absence \\
\hline & Public spending on environmental protection & Presence & Absence \\
\hline & Proper waste disposal & Presence & Absence \\
\hline & Partnerships with other municipalities & Presence & Absence \\
\hline & Regulatory actions & Presence & Absence \\
\hline
\end{tabular}

Source: Prepared by the authors based on SDI Brazil, 2012.

The indexes were selected, classified and organized to compose the variables of the PSIR model (Table 1) according to the environmental reality of the municipalities under study, and to 
measure sustainability in the situational diagnosis of the environmental degradation of the Caatinga areas under study.

The choice of indicators follows the proposal of the Pressure-State-Impact-Response model and its relation of causality among variables aiming to identify the main activities and impacts that cause pressures on the environment studied and their impact on natural resources. Thus, the state of the environment is highlighted and, finally, measures that should be taken to minimize or reverse the environmental degradation to which the Caatinga is submitted in the municipalities studied are discussed.

\subsection{Collection and treatment of data}

Data were collected through an empirical theoretical survey of the main problems related to public administration regarding Environmental Degradation, prospecting with key social and institutional actors from municipalities to identify problems, and local priorities to be mitigated. Interviews were conducted using forms in the three municipalities studied. People selected were adults from both genders and people living around the Conservation Units and/or natural areas, totaling 408 respondents. Authorities and local leaders were also interviewed, as well as officials from the Secretaries of Municipalities, in order to relate the local knowledge to the related variables.

For a better analysis of the dimensions with their respective variables, they were systematized and analyzed in a sequence: preparation of the tables with the analysis of each dimension regarding the municipalities under study, description of the variable, justification of the choice of variable and results.

The variables were analyzed using as a basis absence or presence of sustainability, taking into account the size and based on data from IBGE (2012) secondary information, municipal secretaries, information from city halls employees and interviews with the population and local authorities.

\section{RESULTS AND DISCUSSION}

Three Caatinga areas in the Rio Grande do Norte Seridó, similar in physiognomy, but under different forms of management, were selected in order to assess the environmental degradation of the municipalities with or without Conservation Units.

In the Serra de Santana microregion, Tenente Laurentino Cruz, in the Seridó region of Rio Grande do Norte, covers an area of $65 \mathrm{~km}^{2}$. The city hall of Tenente Laurentino Cruz has an average elevation of $730 \mathrm{~m}$ and coordinates $06^{\circ} 08^{\prime} 52^{\prime \prime} \mathrm{S}$ and $36^{\circ} 43^{\prime} 08^{\prime \prime} \mathrm{W}$ (VELLOSO et al., 2002; Figure 1). The area of Serra de Santana is covered by a shrubby tree vegetation and is a not protected natural area.

The other study areas selected were the municipalities of Serra Negra do Norte, where there is a Federal Conservation Unit; Ecological Station of Seridó (ES Seridó), located geographically between $6^{\circ} 35^{\prime} \mathrm{S}$ and $37^{\circ} 15^{\prime} \mathrm{W}$ (Figure 1), with an area of $1,166.38 \mathrm{ha}$; and the municipality of Jucurutu/RN, where the Private Natural Heritage Reserve (PNHR) Stoessel de Brito is located between $6^{\circ} 13^{\prime} 4^{\prime \prime} S$ and $37^{\circ} 2^{\prime} 25^{\prime \prime} \mathrm{W}$, occupying an area of 756 ha in the Central Mesoregion of Rio 
Grande do Norte (IDEMA, 2012). Both regions are Caatinga resource conservation areas in the northeastern Semiarid within in regions with farms extensively using natural resources, where several negative impacts caused by human activities are observed (SILVA et al., 2009).

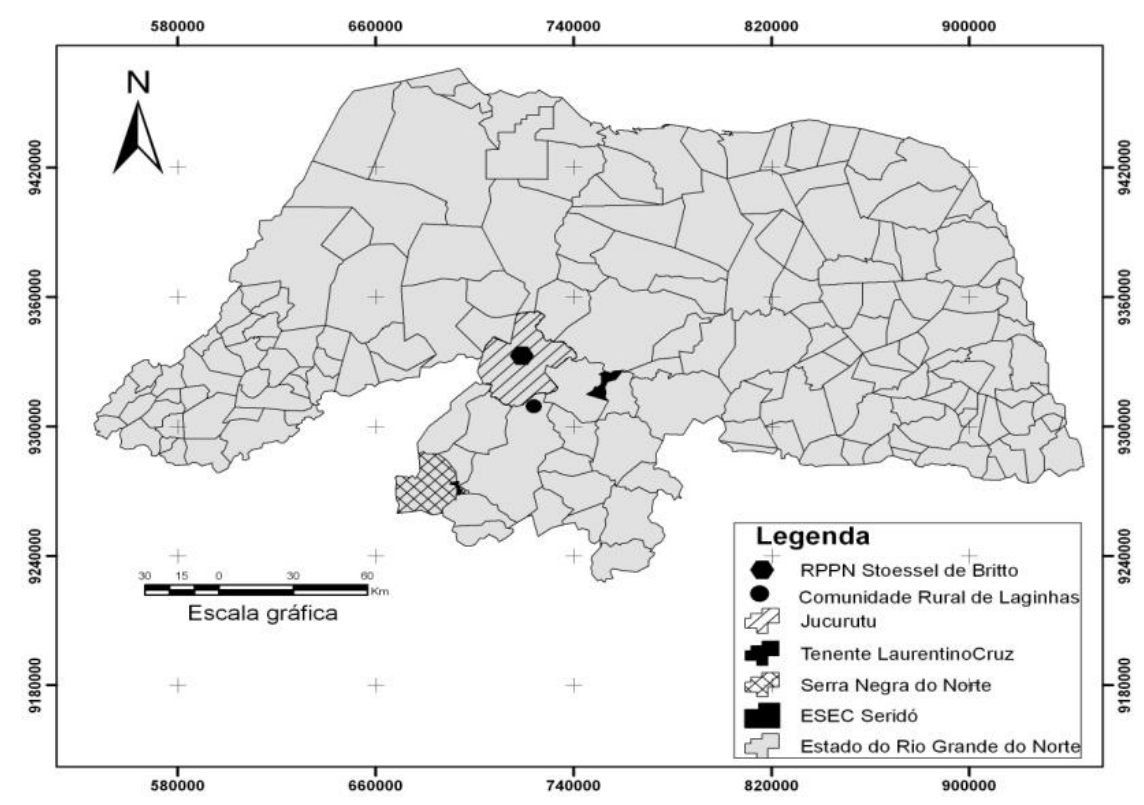

Figure 1: Geographic location of the areas under study. Source: prepared by Dr. Mycarla Lucena.

The problems were identified as priorities for the local management, since they reflect the challenges faced by managers and by the community of municipalities. It is also pertinent to stress that the variables composing the PSIR were defined and established based on a consultation with several authors. Because PSIR is an indicator that reflects the environmental quality of certain locations or situations, it is considered as a variable depending, therefore, on the reality researched.

It is important to note the public consultation made to the local community. The researcher and the planner must be accept through this consultation to be able to perform a job, conduct a research or action that addresses concerns about the environmental quality of a particular location, since only with such attitudes any Action will be successfully implemented.

In this this context and based on the dimensions Pressure, State, Impact and Response studied, Tables 2, 3, 4 and 5 show the environmental situation diagnosed in the analyzed municipalities. From each set of dimensional variables studied, 29 variables were obtained. Regarding the municipality of Serra Negra do Norte, 10 positive results (Favorable) were obtained: 5 for the State dimension, 2 for the Impact dimension and 3 for the Response dimension. Jucurutu had 5 favorable indicators, all for the State dimension. The municipality of Tenente Laurentino Cruz had only 3 positive indicators for the State dimension; the Pressure dimension had no favorable data.

\subsection{Evaluation of the Dimension PRESSURE}

Pressure indicators describe the pressures of human activities causing environmental degradation in the municipalities studied. In this study, the analyzed pressure was caused by 
human activities such as deforestation, fires and hunting, which cause large-scale environmental impacts, thus significantly degrading the environment including the quantity and quality of natural resources. To analyze pressure in a specific way, it is important to know the status or environmental indicators that will be analyzed in the next section because, through activities that pressure the environment, it is possible to know what the consequences for the Caatinga region studied are.

Table 2. Evaluation of the dimension PRESSURE, which composes the PSIR system for the areas studied.

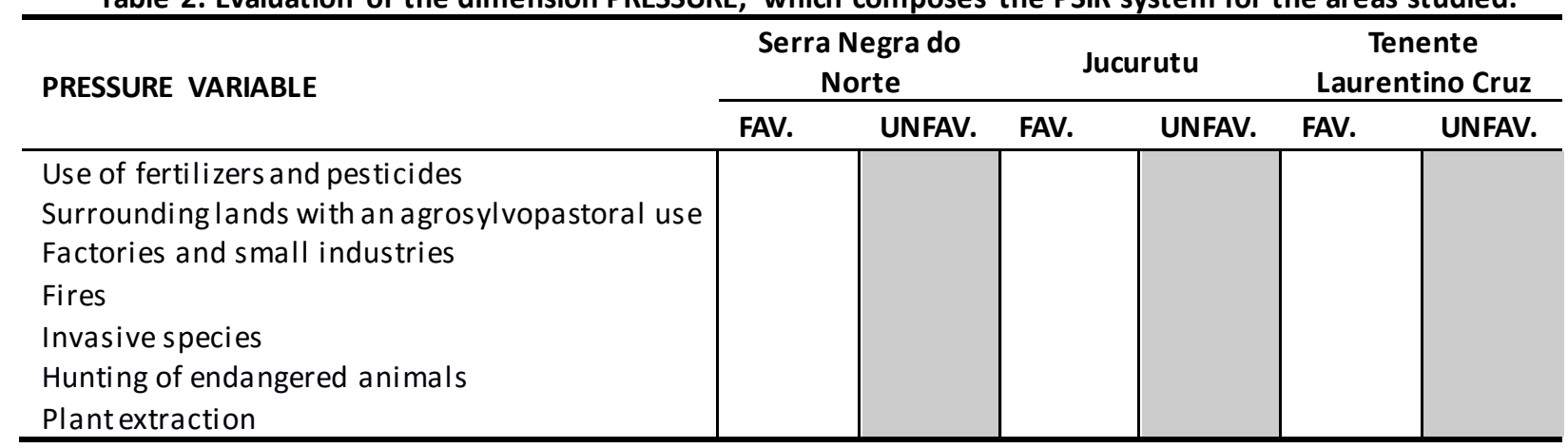

Caption: FAV. - Favorable; UNFAV. - Unfavorable.

\subsubsection{Use of fertilizers and pesticides}

The variables used in the design of this indicator are cultivated area of main crops and amount of pesticides used separated by main use classes (herbicides, fungicides, insecticides, acaricides, mineral oil, sulfur etc.), and the amount of fertilizer sold and delivered to the end consumer. According to the data, all farmers in the three municipalities studied use one or more of these products, assigning to all of them an unfavorable result for the indicator pressure. However, farmers have no other way to prevent the proliferation of pests on their properties.

\subsubsection{Surrounding lands with an agrosylvopastoral use}

The information used in this indicator are areas with temporary and permanent crops, natural and planted pastures areas, areas occupied by forests planted with forest essences, and the class Others including degraded lands (eroded, desert, salted etc.). The surroundings of two Conservation Units studied herein and the forests of Tenente Laurentino Cruz are used in their entirety for such practices, and each year the crop index in family farm areas increases in this region. As a result, the level of deforestation increases (IBGE, 2012). The diagnosis of this indicator was unfavorable for all areas.

\subsubsection{Factories and small industries}

The variables used for this indicator are the presence of factories and/or small industries that do not take proper care regarding sustainability, as is the case of ceramic and food industries such as, for example, flour mills, very common in these three municipalities. The evaluation of this indicator was also unfavorable for all three areas, given that in these municipalities, the presence of these industries is very high and they work without supervision regarding acting in a sustainable manner, causing high losses to the sustainability of the Caatinga. 


\subsubsection{Fires}

It expresses the occurrence of forest fires in a given territory. The variables used are occurrence of fires and area where they happen. According to the monitoring of fires by the Ministry of Environment in the three municipalities, forest fires are frequent. A fact that influences this frequency is fires used for agriculture, which in turn reduces soil fertility. In Tenente Laurentino Cruz, due to the lack of supervision and lack of Conservation Units, this data is even more significant. This indicator was also unfavorable for all three areas.

\subsubsection{Invasive species}

It takes into account the number of invasive species at a site and the main forms and consequences of the invasion. Indirectly, upon modifying natural environments, such as filling and/or clearing a region, man may facilitate the spread of invasive exotic species. Invasive species are also those native from Brazil that started to occur outside their original area. Currently, the introduction and the spread of invasive exotic species is one of the three leading causes of extinction of species in the world (IBGE IDS, 2012). Invasive exotic species compete with native species and may cause the extinction of some of them. This contributes to environmental degradation in the Caatinga and in the municipalities studied. There is the removal of species native to the Caatinga to the detriment of exotic plants that are introduced. This practice greatly undermines the sustainability of municipalities because the presence of these species causes extinctions and, as a result, the three municipalities were classified as unfavorable regarding this indicator.

\subsubsection{Hunting of endangered animals}

This indicator expresses some of the anthropogenic pressures on the wildlife of a territory, which may lead to the extinction of the most sought after species. It comprises of trafficked and seized wild animals and number of breeders of native fauna species and/or species hunted for human consumption.

\subsubsection{Plant extraction}

This indicator shows the existence of plant extraction in the areas studied, either for wood production for trading or for deforestation, and crop planting. This stimulates soil impoverishment and consequently the intensification of environmental degradation in the municipalities.

In the three study areas, deforestation has been the main concern. However, a higher deforestation occurs in Tenente Laurentino Cruz; in addition to deforestation, the trade of wood is as a major alternative to the survival of the rural population. According to the competent agencies of the municipality, the lack of supervision and effective laws that prevent deforestation practices accentuate this situation. The existence of legislation in Serra Negra do Norte (an ES area) and, to a lesser extent, in Jucurutu (a PNHR area) minimizes but does not avoid this situation.

As reported in the description of the three municipalities, they are located in the Caatinga of Rio Grande do Norte. Although they are under different forms of environmental management, they have equal problems, as shown in Table 2. Regarding this variable, it is observed that the pressure was unfavorable for the three municipalities, highlighting its importance to the discussion 
of sustainability in Caatinga. It demonstrates the worrying state of environmental pressures that affect these municipalities.

\subsection{Evaluation of the Dimension STATE}

State is the environmental quality and the quantity of natural resources in a study area. In addition, the current situation of the natural environment and its evolution over time must be evaluated. These activities cause environmental degradation with disastrous consequences. Sustainable activities in these environments must also be observed and analyzed. State activities in the three municipalities are shown in Table 3.

Table 3. Evaluation of the dimension STATE, which composes the PSIR system for the areas studied.

\begin{tabular}{|c|c|c|c|c|c|c|}
\hline \multirow[t]{2}{*}{ STATE VARIABLE } & \multicolumn{2}{|c|}{$\begin{array}{c}\text { Serra Negra } \\
\text { do Norte }\end{array}$} & \multicolumn{2}{|c|}{ Jucurutu } & \multicolumn{2}{|c|}{$\begin{array}{c}\text { Tenente } \\
\text { Laurentino Cruz }\end{array}$} \\
\hline & FAV. & UNFAV. & FAV. & UNFAV. & FAV. & UNFAV. \\
\hline \multicolumn{7}{|c|}{$\begin{array}{l}\text { Vegetation cover } \\
\text { Native fauna diversity }\end{array}$} \\
\hline \multicolumn{7}{|c|}{ Native flora diversity } \\
\hline \multicolumn{7}{|c|}{ Degraded areas } \\
\hline \multicolumn{7}{|c|}{ Protected areas (Conservation Units) } \\
\hline \multicolumn{7}{|c|}{ Extinct and/or endangered species } \\
\hline \multicolumn{7}{|c|}{ Housing a dequacy } \\
\hline \multicolumn{7}{|c|}{ Mapping of degraded area } \\
\hline $\begin{array}{l}\text { Pollution of wate } \\
\text { Desertification }\end{array}$ & & & & & & \\
\hline
\end{tabular}

Caption: FAV. - Favorable; UNFAV. - Unfavorable.

\subsubsection{Vegetation cover}

This indicator measures Caatinga's vegetation area with native cover, for such an area preserves the natural conditions of the soil. Thus, areas with agriculture vegetation are not included in this indicator. Maps available at INPE (2011) for the municipalities studied show that greatest vegetation cover is in Serra Norte do Norte, followed by Jucurutu and Tenente Laurentino Cruz. It provides this indicator with the status favorable for municipalities that have Conservation Units and unfavorable for Tenente Laurentino Cruz.

\subsubsection{Native fauna diversity}

For this indicator, the diversity of native animals and plants of the remaining Caatinga are accounted for in the municipalities studied, for the loss of Biodiversity is one of the causes of Environmental Degradation. The measurement of this indicator, together with the knowledge of the local community and municipal agencies, demonstrates that there is a greater diversity in Serra Negra do Norte. This is because many of the native species extinct in the region were reintroduced due to the implementation of the ES Seridó in the municipality. Thus, this indicator is favorable for that municipality. In Jucurutu, the PNHR is a place where native animals find refuge; thus, this indicator is also favorable. In Tenente Laurentino Cruz, relatively substantial forests are target of hunters, and native animals are not frequently seen. Yet, the indicator is favorable for this municipality due to the Biological Diversity observed in the region. 


\subsubsection{Native flora diversity}

The indicator native flora diversity accounts for existing native plants and their diversity in the municipalities. Here, the results are the same as the previous item, given that the natural environment of the native fauna is the flora. For Serra Negra do Norte and Jucurutu, the list of mentioned native species is greater than the list for Tenente Laurentino Cruz. This grants a favorable indicator to municipalities with CUs and an unfavorable indicator to Tenente Laurentino Cruz.

\subsubsection{Degraded areas}

Degraded areas are those where the soils are exposed, without the presence of native vegetation or plants destined to crops. They are areas disturbed to some degree in its entirety, whether physically, chemically or biologically (EMBRAPA, 2012). In all municipalities, there are degraded areas scattered throughout their rural areas. Therefore, the indicator is unfavorable for all studied areas.

\subsubsection{Protected areas (Conservation Units)}

Conservation Units are one of the oldest alternatives to the preservation of nature (HOEFFEL, 2008). The purpose of this indicator is to measure protected areas, such as legalized Conservation Units, in municipalities. It is possible to verify that in Serra Negra do Norte, the preserved area is the largest, followed by Jucurutu. For both, the indicator is favorable. In Tenente Laurentino Cruz, there are protected areas. Some portions of its area are destined for preservation by IBAMA, but they are not legalized. Because of that, this indicator is unfavorable.

\subsubsection{Extinct and/or endangered species}

The variables used in this indicator are number of endangered species, subdivided by category of risk, and estimated number of native species of a couple of taxa. In the three municipalities, there is a high number of endangered species, even in Serra Negra do Norte, which has the ES Seridó. Some species that were previously extinct were reintroduced. These species are still endangered in Jucurutu and Tenente Laurentino Cruz, and there is no reintroduction plan for these species. Local communities, using native plants and animals for various purposes, such as food and trade, collaborate to reduce endangered animals in their natural environments. Therefore, the indicator is unfavorable for all three areas.

Housing Adequacy - The variables used are total number of permanent private housing units, density of residents per bedroom, waste collection, water supply and sanitation. This indicator is considered satisfactory only for households in urban areas (IBGE Cidades, 2012). However, most evaluated residences are in the rural areas and do not have proper garbage collection, water supply and sanitation. Thus, this indicator is unfavorable for all areas studied.

\subsubsection{Mapping of the degraded area}

The mapping of degraded areas is an indicator that shows the evolution of degraded soils in municipalities. Therefore, it is very relevant to environmental degradation diagnoses. The existence of such a mapping is important so that soil degradation can be monitored. For all three 
areas, the INPE (2011) performed the mapping of degraded areas. It showed that this indicator is favorable for all three municipalities.

\subsubsection{Pollution of water resources}

Water pollution may have an environmental or chemical origin (pesticides and industrial waste). The water resources of municipalities consist of intermittent rivers, streams, reservoirs and wells, characteristic of Caatinga areas. The way communities use these resources leads to its pollution, given that there are numerous ceramic factories and flourmills that pollute the soil and consequently the water bodies. Water pollution was found in all three municipalities, and thus this indicator is unfavorable for all three areas.

\subsubsection{Desertification}

It expresses the process of environmental degradation of the soil and other natural resources, resulting from both climatic variations and human activities. The areas studied are in semiarid regions and, according to INPE (2011), have several regions going through a desertification process. Areas are thus classified as severe according to the level of environmental degradation. Therefore, the three municipalities are classified as unfavorable for sustainability in this respect.

The state observed for the three municipalities is alarming, as the indicators show that even in Serra Negra do Norte and Jucurutu, where there is a greater presence of favorable indicators, there is still a high number of unfavorable indicators regarding issues important to the region, such as desertification and pollution of water resources. These factors reflect impacts that worsen the environmental degradation.

\subsection{Evaluation of the Dimension IMPACT}

The environmental degradation process is relevant to society because it is the consequence of negative environmental impacts. The negative impacts are the destruction of fauna, flora, physical, and chemical soil losses, which directly affects biodiversity causing a significant loss of soil productivity, among other environmental losses.

Table 4. Evaluation of the dimension IMPACT, which composes the PSIR system for the areas studied.

\begin{tabular}{|c|c|c|c|c|c|c|}
\hline \multirow[t]{2}{*}{ IMPACT VARIABLE } & \multicolumn{2}{|c|}{$\begin{array}{c}\text { Serra Negra } \\
\text { do Norte }\end{array}$} & \multicolumn{2}{|c|}{ Jucurutu } & \multicolumn{2}{|c|}{$\begin{array}{c}\text { Tenente } \\
\text { Laurentino Cruz }\end{array}$} \\
\hline & FAV. & UNFAV. & FAV. & UNFAV. & FAV. & UNFAV. \\
\hline \multicolumn{7}{|l|}{ Abandoned domestic animals } \\
\hline \multicolumn{7}{|l|}{ Contamination by solid waste (litter) } \\
\hline \multicolumn{7}{|l|}{ Reduction in the productivity of properties } \\
\hline \multicolumn{7}{|l|}{ Sociocultural projects } \\
\hline \multicolumn{7}{|l|}{ Control of exotic fauna and flora } \\
\hline Spending on Research and Development & & & & & & \\
\hline
\end{tabular}

Caption: FAV. - Favorable; UNFAV. - Unfavorable.

\subsubsection{Abandoned domestic animals}

Domestic animals abandoned in natural areas may cause damage to the fauna and flora. This indicator measures the absence or presence of these animals in natural areas of municipalities. 
Given the presence of domestic animals in all the forests of the three municipalities, abandoned domestic animals cause damage because they prevent a proper development of native vegetation and wild animals. This is, therefore, an unfavorable indicator for all three areas studied.

\subsubsection{Contamination by solid waste (litter)}

Contamination by solid waste is one of the most relevant indicators to measure environmental degradation. As discussed previously, there is no proper garbage disposal for the entire population of the municipalities studied, given that the rural population does not have a regular waste collection. Thus, communities dispose their garbage on lands near forests, which may ultimately contaminate water bodies. This is a source for transmission of diseases, among other negative impacts. Thus, this indicator is unfavorable for all three areas.

\subsubsection{Reduction in the productivity of properties}

It is an important impact caused by environmental degradation in areas where agriculture is one of the main activities of income. The rural production rate of the communities in the three municipalities, according to IBGE (2010), has been decreasing due to soil depletion rates, which increase due to human urban impacts. Only in Serra Negra do Norte the productivity has remained above 14 tons, which makes it a favorable indicator. On the other hand, in Jucurutu and Tenente Laurentino Cruz this indicator is unfavorable. The productivity in these municipalities reduced to less than 4 tons, a low value when compared to what farmers reported in their interviews and obtained in their properties in recent years.

\subsubsection{Sociocultural Projects}

This indicator demonstrates the presence or absence of social projects that promote a relationship between people and sustainable practices so that there is a possible reduction in environmental impacts in the municipalities. What can be observed with this indicator is that in all three municipalities, there are only specific projects, mostly performed in schools, without a proportion or investments to be able to reverberate in reducing environmental impacts. Thus, this indicator is unfavorable for all three Caatinga areas studied.

\subsubsection{Control of exotic fauna and flora}

It is a region with animal and plant extraction, in which the Community introduces plants for livestock farming practices and domestic animals for socialization and handling of the land. These practices are present in all three environments. However, in Serra Negra do Norte, with some control measures imposed by the ES Seridó, exotic animals have been controlled and exotic plants removed from Ecological Station areas. Thus, this indicator is favorable for Serra Negra do Norte. In Jucurutu and Tenente Laurentino Cruz, the control of exotic animals and plants is incipient, without proper guidelines for this control. The indicator is unfavorable for these municipalities. 


\subsubsection{Spending on Research and Development}

Investments made by municipal authorities in research and development of Caatinga areas are very scarce. No specific project was found in city halls files within Caatinga areas, which is detrimental to the sustainability because municipalities with a higher investment in their environmental area tend to be more sustainable. As a result, this indicator is unfavorable for all three municipalities.

The impact is caused by the condition of the area, which may reflect on different aspects such as quality of human life, local economy and ecosystems. What was obtained with this dimension is reflected only on Serra Negra do Norte. Therein, a condition more favorable than in other municipalities can be observed, making the impacts negative, causing further damage and accentuating the environmental degradation of this region.

\subsection{Evaluation of the Dimension RESPONSE}

Society responds to environmental problems causing environmental degradation in order to correct them, prevent the negative effects of human activity on the environment, promote the preservation and conserve nature. Response measures should be taken as soon as pos sible so that impacts are minimized as much as possible and environmental state changes are corrected in the best way. In Table 5, the Response indicators are shown in order to analyze the relation between environmental sustainability and degradation.

Table 5. Evaluation of the dimension RESPONSE, which composes the PSIR system for the areas studied.

\begin{tabular}{|c|c|c|c|c|c|c|}
\hline \multirow{2}{*}{ RESPONSE VARIABLE } & \multicolumn{2}{|c|}{$\begin{array}{c}\text { Serra Negra } \\
\text { do Norte }\end{array}$} & \multicolumn{2}{|c|}{ Jucurutu } & \multicolumn{2}{|c|}{$\begin{array}{c}\text { Tenente } \\
\text { Laurentino Cruz }\end{array}$} \\
\hline & FAV. & UNFAV. & FAV. & UNFAV. & FAV. & UNFAV. \\
\hline \multicolumn{7}{|l|}{ Associations or environmental cooperatives } \\
\hline \multicolumn{7}{|c|}{ Environmental management public policies } \\
\hline \multicolumn{7}{|c|}{ Public spending on environmental protection } \\
\hline \multicolumn{7}{|l|}{ Proper waste disposal } \\
\hline \multicolumn{7}{|l|}{ Partnerships with other municipalities } \\
\hline Regulatory actions & & & & & & \\
\hline
\end{tabular}

Caption: FAV. - Favorable; UNFAV. - Unfavorable.

\subsubsection{Associations or environmental cooperatives}

Environmental cooperatives are very important strategies for the environmental management decision-making to occur in a more participatory way, and the existence of such associations becomes very positive for environmental sustainability levels. In none of the three municipalities, the existence of these cooperatives was observed. This is thus an unfavorable indicator.

\subsubsection{Environmental management public policies}

The purpose of this indicator is to verify how the government acts so that public actions collaborate with sustainability in municipalities. The municipal governments have to plan public actions for environmental management. However, only in Serra Negra do Norte policies were 
realized. In the ES Seridó, some actions are effectively applied. This a favorable indicator for this municipality and an unfavorable indicator to the others.

\subsubsection{Public spending on environmental protection}

Public spending allocated to environmental protection is lower in Tenente Laurentino Cruz compared to the other municipalities. These expenses can be considered favorable only to the sustainability in Serra Negra do Norte because they are directed to maintain the ESSeridó and not the municipality as a whole, including other rural areas.

\subsubsection{Proper waste disposal}

Waste is a major cause of environmental degradation. It promotes water and soil pollution if inadequately disposed. In the rural zone, which is where the forests studied are concentrated, the population dispose most of the waste it produces outdoors, increasing the levels of environmental degradation in all three municipalities. Therefore, this indicator is unfavorable for all three areas.

\subsubsection{Partnerships with other municipalities}

If the municipality establishes partnerships with neighboring municipalities, the monitoring of their rural and native vegetation areas becomes easier. As many of these areas are in more than one municipality, they require the attention of more than one public official. When this situation occurs, it is essential for such natural areas that different administrations have the same vision and adopt the same management of these natural resources. In all three municipalities, such partnerships were not found and the response indicator is also unfavorable.

\subsubsection{Regulatory actions}

Regulatory actions have been restricted to environmental enforcement and fines to the communities that use natural resources. However, education and environmental awareness are important so that environmental sustainability is possible. In Serra Negra do Norte, communities have adapted to the laws governing the operation of the ES and its buffer zone. This is a favorable indicator. For the other municipalities, where there is no specific environmental legislation, this indicator is unfavorable.

The evaluation of pressure, state and impacts caused to the environment and the consequent environmental degradation of Caatinga areas studied and their respective municipalities enables stating that the environmental quality of these municipalities is unsatisfactory. In addition, society has not demanded actions aimed to conserve natural resources, and restore and maintain environmental quality. Consequently, there have been few answers from the government to mitigate the situation. This directly reflects on the assessments of the RESPONSE dimension. According to data shown in Table 5, only the municipality of Serra Negra do Norte has satisfactory responses. This situation is critical, given that these three areas are strategic to the conservation of the Caatinga. In the case of Serra Negra do Norte, after 10 years studying the herpetofauna, all species found in this $\mathrm{CU}$ are common to other Caatinga areas of the Region. In contrast, after only two years of study in Tenente Laurentino Cruz, three new occurrences of species were recorded for the Rio Grande do Norte state (GOGLIATH, 2012). This example makes 
the environmental degradation situation observed even more worrying. It may cause direct consequences, thus requiring answers regarding the biodiversity conservation of the Caatinga.

\section{CONCLUSIONS}

The diagnosis about the sustainability of the three municipalities reveals that Serra Negra do Norte is in a more favorable situation than the municipalities of Jucurutu and Tenente Laurentino Cruz. The indicators that highlights this municipality are those that highlight the supervision and well-being of society because of the existence of the ES Seridó (see Tables 2, 3, 4, and 5), considering that the ES is more accepted by society than the PNHR Stoessel de Brito (SILVA et al., 2011). This Conservation Unit has contributed to the environmental sustainability of the Caatinga region. Although to a lesser extent, the PNHR Stoessel de Brito also contributes to the sustainability of its region, despite the lower acceptance by the local community.

Regarding the purposed objective, that is, to diagnose the problems that cause environmental degradation in the municipalities of Serra Negra do Norte, Jucurutu and Tenente Laurentino Cruz using the System Sustainability Indicator Pressure-State-Impact-Response (PSIR), in addition to portraying degradation it showed that this indicator was efficient to evaluate the municipal management aiming conservation.

In Tenente Laurentino Cruz, the existence of Caatinga native vegetation contributes to the environmental sustainability. However, without a proper management, this municipality is at a level of environmental degradation higher than other municipalities. Therefore, it requires government actions in various fields in addition to the designation of a Conservation Unit to improve the municipality's sustainability levels. This action, even in cases in which they are not well managed, provide an improvement of the environmental conservation status.

Given the environmental challenges faced by these communities in the Caatinga, the use of new types of assessment of environmental impact and of public management is necessary. Methods and tools should be used to assist in problem solving and in the exposure of results. A periodic measurement of environmental determinants of municipalities might assist in the preparation of laws, objectives and strategies of public actions, strengthening the community and environmental organizations and improving public services so that a more participatory environmental conservation is possible in these semiarid regions.

\section{BIBLIOGRAPHIC REFERENCES}

1. ALVES, J. J.A.; ARAÚJO, M. A.; NASCIMENTO, S. S. Degradação da caatinga: uma investigação ecogeográfica. Caminhos de Geografia Uberlândia v.9, n.26 . p. 143 - 155. 2008.

2. ALVES, J.J.A. Caatinga do cariri paraibano. GEONOMOS v. 17, n1, p. 19 - 25, 2009.

3. ARIZA, C. G.; NETO, M.D.A; contribuições da geografia para avaliação de impactos ambientais em áreas urbanas, com o emprego da metodologia pressão - estado-impacto - resposta (P.E.I.R.). Caminhos de Geografia. Uberlândia, v. 11, n. 35, p. 128 - 139. 2010.

4. BERTONI, J.; LOMBARDI NETO, F. Conservação do solo. 3. ed. São Paulo: Ícone, 1990.

5. BRASIL. Ministério do Meio Ambiente. Disponível em http://www.mma.gov.br acesso em: 20 de maio. 2012. 
6. BRASILEIRO, R S. Alternativas de desenvolvimento sustentável no semiárido nordestino: da degradação à conservação. Scientia Plena, V. 5, N. 5, 2009.

7. BROLLO M.J. Metodologia automatizada para seleção de áreas para disposição de resíduos sólidos: Aplicação na Região metropolitana de Campinas (SP). São Paulo, 2001. Tese de Doutorado, Faculdade de Saúde Pública, Universidade do Estado de São Paulo, 2001.

8. BROLLO M.J. BARBOSA J.M., ROCHA F.T., MARTINS S.E. Programa comum de pesquisa em caracterização e recuperação de áreas degradadas. In: CINP/SMA, Reunião Anual sobre Pesquisa Ambiental a Pesquisa Cientíica e Tecnológica e a Gestão Ambiental, 5, São Paulo, Anais, p. 74-82. 2002.

9. CANDIDO, H. G.; BARBOSA M. P.; SILVA M. J. Avaliação da degradação ambiental de parte do Seridó paibano. Revista Brasileira de Engenharia Agrícola e Ambiental, v.6, n.2, p.368-371, 2002.

10. CARVAlHo, P. G. M.; BARCEllos, F. C. Construindo indicadores de sustentabilidade. Indicadores Econômicos. FEE, v. 37, p. 2280-2656, 2009.

11. CHUNG, E.S.; LEE, K. S. Prioritization of water management for sustainability using hydrologic simulation model and multicriteria decision making techniques. Journal of Environmental Management v.90, p. 1502-151, 2009.

12. DIAS, R. S. F. Intervenções públicas e degradação ambiental no semiárido cearense (O caso de Irauçuba). Fortaleza, 1998. Dissertação de Mestrado- Desenvolvimento e Meio Ambiente, PRODEMA. Universidade Federal do Ceará. 1998.

13. EMBRAPA. Avaliação e recuperação de areas degradadas. Disponível em: http://www.cnpma.embrapa.br/unidade/index.php3?id=229\&func=pesq acesso em: $31 / 08 / 2015$.

14. FAO - Food and Agriculture Organization of the United Nations. Esquema Pressão-SituaçãoResposta e Indicadores Ambientais. Disponível em: http://www.fao.org/ag/againfo/ programmes/pt/lead/toolbox/Refer/EnvIndi.htm. Acesso em 10 de maio de 2013.

15. FERNANDES, E. A.; CUNHA, N.R.S.; SILVA, R.G. Degradaçâo ambiental no estado de Minas Gerais. Revista de Economia e Sociologia Rural, v.43, p.179-198, 2005.

16. FREIRE, E.M. X.; CÂNDIDO, G.A.; AZEVEDO. P.V. (Org.). Múltiplos olhares sobre o semiárido brasileiro: perspectivas interdisciplinares. 01 ed. Natal: EDUFRN, 2011, v. 01, p. 11-35.

17. GOGLIATH, M.. Composição, diversidade, ecologia e comportamento termorregulatório de espécies de Squamata em área serrana de caatinga, nordeste do Brasil. Natal, 2012. Tese de Doutorado - Programa de pós graduação em psicobiologia. Universidade Federal do Rio Grande do Norte. 2012.

18. HOEFFEL J. L.; FADINI, A. A.B.; MACHADO, M. K.; REIS, J. C. Trajetórias do Jaguary - unidades de conservação, percepção ambiental e turismo: um estudo na APA do Sistema Cantareira, São Paulo. Ambiente \& Sociedade, Campinas v. 11, n. 1, p. 131-148, 2008.

19. HUANG, H. F.; KUO, Jeff; Lo, S. L. Review of PSR framework and development of a DPSIR model to assess greenhouse effect in Taiwan. Environ Monit Assess. v. 177, p. 623-635. 2011.

20. IBGE Censo. Censo 2010 do estado do Rio Grande do Norte. Disponível em: http://www.censo2010.ibge.gov.br/amostra/index.html?cancelload=true Acesso em: $01 / 12 / 2015$ 
21. IBGE Cidades. Rio Grande do Norte. Disponível em: http://www.ibge.gov.br/cidadesat/ topwindow.htm?1 Acesso em: 01/12/2015

22. IBGE IDS. ÍNDICE DE DESENVOLVIVIMENTO SUSTENTÁVEL Brasil 2010. Estudos e Pesquisas: Informação Geográfica. Ministério do Planejamento, Orçamento e Gestão. Instituto Brasileiro de Geografi a e Estatística - IBGE. n. 7. 443 p. 2010.

23. IBGE IDS. ÍNDICE DE DESENVOLVIVIMENTO SUSTENTÁVEL Brasil 2012. Estudos e Pesquisas: Informação Geográfica. Ministério do Planejamento, Orçamento e Gestão. Instituto Brasileiro de Geografi a e Estatística - IBGE. n. 9. 350 p. 2012.

24. IDEMA. 2012. Instituto de Desenvolvimento Sustentável e Meio Ambiente do Rio Grande do Norte. Governo do Estado do Rio Grande do Norte. Disponível em: www.idema.rn.gov.br/, Acesso em 03/12/2015).

25. INPE. Grupo de geoprocessamento do CRN: Mapas municipais. Disponível em: http://www. nctn.crn2.inpe.br/mapas municipais.php Acesso em: 01/12/2015

26. KRISTENSEN, P. The DPSIR Framework. In: workshop on a comprehensive/detailed assessment of the vulnerability of water resources to environmental change in africa using river basin approach, 27-29 September 2004, Nairobi, Kenya. Nairobi: UNEP Headquarters, 2004.

27. MENEGUZZO, I. S. Análise da degradação ambiental na área urbana da bacia do Arroio Gertrudes, Ponta Grossa, PR.: uma contribuição ao planejamento ambiental. Paraná, 2006. Dissertação de Mestrado - Curso de Pós-Graduação em Ciência do Solo, Universidade Federal do Paraná. 2006.

28. MONTEIRO, M. Desertificação ameaça o nordeste brasileiro. Revista Ecologia e Desenvolvimento, Rio de Janeiro, n. 51, p.15-19, mai. 1995.

29. NOBRE, A.M.; ROBERTSON-ANDERSSON, D.; NEORI, SANKAR, A. K. Ecological-economic assessment of aquaculture options: Comparison between abalone monoculture and integrated multi-trophic aquaculture of abalone and seaweeds. Aquaculture 306 116-126, 2010.

30. OECD - Organization for Co-Operation and Development. OECD Environmental Indicators: Development, Measurement and Use: Reference Paper. OECD, 2004.

31. PRUDÊNCIO, M. A.; CÂNDIDO, D. K. Degradação da vegetação nativa do município de Assú/RN: indicadores e ações mitigadoras Sociedade e Território, Natal, v. 21, n. 1, p. 144 -156, 2009.

32. SEKOVSKI, I,; NEWTON, A.; DENNISON, W. C. Megacities in the coastal zone: Using a driverpressure-state-impact-response framework to address complex environmental problems. Estuarine, Coastal and Shelf Science, v.96, p. 48-59, 2012.

33. SILVA, T. S.; CÂNDIDO, G. A.; FREIRE, E. M. X. conceitos, percepções e estratégias para conservação de uma estação ecológica da caatinga nordestina por populações do seu entorno. Sociedade \& Natureza, Uberlândia, v. 21, n. 2, p. 23-37, 2009.

34. SILVA, T. S.; LUCENA, M.M.A.; FREIRE, E. M. X. ; CANDIDO, Gesinaldo Ataíde. Conservação da Caatinga: interdisciplinaridade e percepção de comunidades do semiárido. In: Eiza Maria Xavier Freire, Gesinaldo Ataíde Cândido, Pedro Vieira de Azevedo. (Org.). Múltiplos olhares sobre o semiárido brasileiro: perspectivas interdisciplinares. 01 ed. Natal: EDUFRN, 2011, v. 01, p. 11-35.

35. SILVA, R. G.; RIBEIRO, C. G. Análise da Degradação Ambiental na Amazônia Ocidental: um 
Estudo de Caso dos Municípios do Acre. RER, Rio de Janeiro, v. 42, n, 1, p. 91-110, 2004.

36. VELLOSO,A.L; SAMPAIO, E. V. S. B.; PAREYN, F. G.C. (Eds.). 2002. Ecorregiões propostas para o Bioma Caatinga. Recife: Associação Plantas do Nordeste, Instituto de Conservação Ambiental, The Nature Conservancy do Brasil.

37. VIDAL, F.C.B. A problemática do semi-árido nordestino à luz de Celso Furtado: permanência da pobreza estrutural. In: Pobreza e desigualdades sociais. Salvador: SEI, 2003, v. 1, p. 197217. 2003.

38. VIEIRA, S. J. Transdisciplinaridade aplicada à Gestão Ambiental de Unidade de Conservação. Estudo de Caso: Manguezal do Itacorubí, Florianópolis/SC. Sul do Brasil. Tese de Doutorado. Programa de pós-graduação em engenharia civil- UFSC, Florianópolis, 292 p. 2007. 